\title{
Increasing Academic Self-Efficacy Through Group Guidance in Class VIII Students of SMP Negeri 25 Banjarmasin
}

\author{
Ririanti Rachmayanie $\mathrm{J}^{1^{*}}$, Eklys Cheseda Makaria ${ }^{2}$ \\ ${ }^{1}$ Faculty of Teacher Training and Education, Lambung Mangkurat University \\ ${ }^{2}$ Faculty of Teacher Training and Education, Lambung Mangkurat University \\ *Corresponding author. Email: ririanti.bk@ulm.ac.id
}

\begin{abstract}
Academic self-efficacy is a determining factor in students' academic performance in school. The reality that occurs in the world of education, especially in Indonesia is that students get a lot of pressure, especially in academics. The academic value demands that must meet the minimum completeness criteria, without being accompanied by a pleasant learning ambiance are often experienced by students in Indonesia. This situation can trigger a decrease in the motivation and commitment of students to study. To avoid this, the counselor needs to make efforts, one of which is group guidance. This study aims to improve the academic self-efficacy of class VIII students at SMP Negeri 25 Banjarmasin, which is characterized by changes in student learning behavior. This research is qualitative research using a type of action research. The results of action research indicate a change in behavior in learning, namely students have self-confidence in learning so they have the belief to be able to complete difficult tasks and take on challenges in learning.
\end{abstract}

Keywords: Academic Self-Efficacy, Group Guidance

\section{INTRODUCTION}

Academic self-efficacy is the most influential predictor of academic performance [1] Academic selfefficacy will work when individuals are in a stressful situation. Individuals with low levels of academic selfefficacy will easily feel anxious, depressed, tense, and feel inadequate in the face of their academic duties. Conversely, individuals who have high levels of academic self-efficacy will be more confident with their ability to complete academic assignments, both in preparation and execution of tasks [2]. The feeling of being able and optimistic is contained in this academic self-efficacy that makes the students' academic selfefficacy need to be improved.

The effect of academic self-efficacy on academic performance is demonstrated in research conducted [3] found academic self-efficacy predicting academic performance with $\beta=0.151, p<0.01$ [4] found that academic self-efficacy was positively and significantly influential with a value of $\mathrm{R}=0.39$ (P. < 0.05) on academic performance. The academic performance of students in Indonesia generally can be seen from the assessment of the following international institutions, the results of the PISA (Program for International Student Assessment) survey on education and ability of school students in 2012 showed Students in Indonesia ranks at 64 from 65 countries (www.kompasiana.com). In line with the results of TIMSS (Trends in International Mathematics and Science Studies) in 2011, Indonesian students are ranked 38 from 42 countries in mathematics, the order of 40 from 42 countries in the field of Science (nasional.kompas.com). Results of Progress in International Reading Literacy Study (PIRLS) in 2011 also put Indonesia in the order of 42 from 45 countries (nasional.kompas.com). The result of the International Assessment Agency is one of the evidence that the academic performance of students in Indonesia is worrying.

Junior High School (SMP) students are faced with complex life and learning situations, full of tasks, burdens, challenges, and opportunities. Many students experience learning problems, including low selfefficacy in learning which is characterized by lack of motivation to learn, delaying assignments, avoiding the burden of learning, giving up easily, and so on, so that learning achievement is not optimal.

Based on the results of interviews with counselors, that of the four areas of guidance and counseling, in terms of learning is the most problems that occur in students at SMPN 25 Banjarmasin. Where conditions 
are seen students lack the ability to complete difficult tasks, unable to recognize their strengths so that students do not have confidence in learning. This situation can ignite the student's motivation and commitment to study.

Seeing the fact, the school is required to improve guidance and counseling services. The student's side is required to have academic self-efficacy, to be able to face the demands of the learning tasks. To improve student's academic self-efficacy, including through guidance and counseling services. In guidance and counseling services requires an effective guidance and counseling strategy. There are various theories, strategies, models in guidance and counseling services.

Peer groups are important in the lives of teenagers in junior high school. Therefore, the right strategy to increase academic self-efficacy is a group strategy. One of the group's strategies is group guidance. In group guidance, students will be together with their peers ' groups to learn a skill and accomplish a specific goal.

To change the behavior in accordance with the research objectives, it is necessary to determine an action as research problem-solving. The determination of action is based on theoretical studies relevant to the research problem. In this study, actions were determined based on the theories studied, namely on adolescents ' characteristics, academic self-efficacy, and group guidance services.

The characteristics of students or adolescents are interpreted as traits inherent in junior high school students who are distinctive and distinguish them from other students in the education unit. The characteristics of the junior high school students that need to be understood include physical, cognition, social, emotional, moral, and spiritual aspects.

In line with its level of cognitive development, junior high school students often questioned the religiosity that had previously been believed and held firmly. Consequently, many youths reconsider their religious beliefs, experiencing a decline in worship due to doubts over previous beliefs. On the other hand, this doubt on some junior high school students encourages them to seek information and retest the truths they believe.

Adolescent mortality has also undergone a fairly basic change compared to childhood. Therefore, the students of junior secondary school often question matters related to morality that have been previously believed to be true.

The development of the junior high school students, in general, has an emotionality that is still labil. The transition of physical, cognitive, and social aspects leads to easy changing adolescents ' emotionality. The cognitive development stage of adolescents can think the formal operations are more hypothesized and abstract, systematic and scientific in solving problems. As a result, teenagers become critically critical so that adults are "dissident", have a high sense of curiosity, egocentric, and think adults are unable to understand them. This causes many adolescents to have conflicts with others, especially with adults.

Socially, people view junior high school students are no longer children, but not yet recognized as adult individuals. This situation makes junior high school students (teenagers) feel treated inconsistently. In addition, teenagers do not like it if they are treated as children, but are objected if it is required to be fully responsible as adults in general.

Physical junior high school students grow rapidly as a result of hormones and organs, especially related to hormones and sexual organs. Rapid physical growth at this time has consequences for changes in other aspects such as sexuality, emotionality, and psychosocial aspects.

In addition to paying attention to various aspects that are characteristic of junior high school students (teenagers), it is also important to help them achieve their developmental tasks. Achievement of developmental tasks is targeted guidance and counseling services. Guidance and counseling services are one of the facilities to help the counselee to achieve their development tasks optimally.

Self-efficacy is a term created by Albert Bandura to illustrate a person's beliefs towards his ability to accomplish tasks. Self-efficacy is based on the framework of the social cognitive theory that sees human behavior as a result of learning by observing its environment. [5] Self-efficacy is an individual belief in their talents and abilities, which will have a pleasant impact on their actions and as a deciding factor in behavior. The opinion leads to the concept that selfefficacy affects individual choice, way of action, level of effort, diligence, and adaptability [6]. It is similar to [7] that self-efficacy affects how people think, feel, motivate themselves, and act.

Academic self-efficacy can be formed and developed from four ways or sources of information [8]. The four ways are the enactive mastery experience, the vicarious experience, social persuasion, and the physical and emotional states (the state of physiology and emotion). The most influential source on the formation and development of academic self-efficacy is the enactive mastery experience or experience that has been experienced before.

The Enactive Mastery experience or personal experience that has been experienced has been an authentic proof for the individual about its success and failure. These personal experiences will have an impact on the individual's ability to measure their own abilities, 
interpret their experiences, and create confidence in their abilities [9].

The second way to shape and develop academic selfefficacy is through vicarious experience (the experience of others). The source of information in this way is obtained from observing social models. In the vicarious experience concept there is a modeling process, that is, individuals learn from the experience of successes and failures of others who are modeled.

Social persuasion is a third way to shape and improve one's academic self-efficacy. Social persuasion establishes and enhances academic self-efficacy through verbal reinforcement that encourages individuals to be confident of his or her academic ability. Social persuasion has a limited impact on individuals, as it only uses verbal encouragement given by others [10].

The fourth way to shape and improve academic selfefficacy is to improve physical and emotional states (overwhelmed with physiology and emotions). Individuals rely on feelings in assessing their abilities [11]. Individual interpretations of their physical and mood influences affect the individual's self-efficacy.

Panduan Operasional Pelaksanaan (POP) Guidance and Counseling in junior high school explains that the group guidance strategy is assistance to small groups of 2-10 students/counselees so that they are able to prevent problems, maintain values, and develop skills life needed. In general, group guidance is the process of giving assistance given to individuals in group situations. The definition of group guidance is more simply pointing to the guidance activities given to individual groups who experience the same problem [12] Group guidance aims to provide opportunities for students to learn important things that are useful for directing themselves related to personal, social, learning and his career.

To become an effective group, the counselor must facilitate each stage of group formation. There are five stages that the group must pass to become an effective group, namely (1) the orientation stage; (2) the stage of fostering group norms and objectives; (3) the stage of overcoming conflicts in groups; (4) productivity stage; and (5) the stage of ending the group [13].

Group guidance helps students to improve their academic self-efficacy through an enactive Mastery experience strategy, the vicarious experience, social persuasion, and physical and emotional states. The results achieved by students through previous experience are important sources of information because they are directly related to one's personal experience [14]. The group will help students/contemplated to dig into the strengths of experiences previously experienced, or those learned from others that could be the basis for the students ' strengthening and contemplate of the ability It has. Group guidance will also facilitate the vicarious experience, i.e. individuals learn from the success experience as well as the failure of others. Group members in group guidance will also provide verbal reinforcement that encourages individuals to be confident of his or her academic ability. In groups, each member will also be encouraged to engage in the learning process, physical involvement in the learning process is also influential in the physical and emotional states.

\section{METHODS}

This study uses a qualitative approach, which explains the phenomena of the results of research that are descriptive in nature and tend to use analysis. The data obtained were analyzed by the type of action research. This is confirmed by Robbin Mc Taggart who states that action research (Action Research / AR) is collective self-reflective research conducted by participants in social and educational sciences to improve understanding and implementation of their own work, and also have an impact on the surrounding environment

Action Research can be performed by managers, directors, lecturers, teachers, or other social workers, and may contain elements; (a) improve its own work, (b) collaboratively with other persons or groups to improve their work, (c) collaboratively with other agencies separately to bring up the project or develop a new system.

The primary purpose of this research is to change the behavior of its research, the behavior of others, and or to change the workways, frameworks, organizations, or other structures, which in turn result in changes in the behavior of the researchers and OR behavior of others.

Action research has a specific research procedure [20]. The procedure forms a spiral-like cycle consisting of planning, action, observation, and reflection. If the change is not yet as expected, the cycle is repeated again; Planning, action, observation, and reflection. As a whole, the action is applied in research actions through several stages.

The first step is to prepare a plan of action and be known as planning, namely preparing a Rencana Pelaksanaan Lapangan (RPL) and observation sheet accompanied by a rubric as a guideline for observing service delivery with three observation sheets, namely: (a) Observation sheet of counselor activities in carrying out counseling activities, which begin with the formation stage, namely the stage of introduction, self-involvement, the inclusion of the counselee in the new world, namely as part of a new group formed jointly between the counselor and the members who have been determined. Followed by the intermediate stage, which is the 
"bridge" between the first and third stages, where at this stage is explaining the activities to be taken in the next stage, offering or observing whether the members are ready to carry out activities in the next stage, increasing the participation of members. The activity stage is the core of the group activities and the closing stage is the assessment and follow-up, the purpose of revealing group members' impressions about the implementation of activities; (b) Observation sheet of student activities in counseling using group guidance services, with four aspects that will be observed; (c) Observation sheet the results of increasing student academic self-efficacy. Before conducting counseling and counseling action research using group guidance services for class VIII students who indicated having low academic selfefficacy, an initial meeting was held with researchers and counselors to equate perceptions as well as meeting indicated students with low academic self-efficacy problems to build rapport with these students. This research activity involves counselors as partners of collaborative and university students.

The second stage is the implementation of actions, namely the implementation of the design, or providing action. Where the factors examined in this Action Research are the use of group guidance services to improve academic self-efficacy, which consists of factors in counselor activity, student factors, and implementation of group guidance services. The factor of the counselor is the activity of the counselor in providing group guidance services carried out by researchers, namely formulating steps for group guidance consisting of four stages: (1) the stage of formation; (2) transitional stage; (3) stage of activity; and 4) termination stage. Student factors are student activities that can be seen and measured when participating in group guidance services. This can be seen from: (1) being able to maintain confidentiality; (2) help each other in discussing and solving problems; (3) listening to the material presented; and (4) discuss and share opinions and express the impressions and results of activities. The use of group guidance services to improve students' academic self-efficacy, where after following the group guidance services students can: (1) recognize their strength so they have confidence in learning; (2) students are able to interpret physical and mood conditions so that they are confident in their ability to learn; and (3) students are able to make verbal reinforcement to be able to complete learning tasks.

The third stage is observation, namely the implementation of observations by observers (counselors) to respond and provide input on the results of observations of the activities of the counselor, student activities, and the results of actions in the cycle I-IV. The last stage is the reflection stage, which is an activity to restate what has happened when the researcher has finished taking action to students who are given group guidance.

\section{RESULT AND DISCUSSION}

Based on the observation of the counselor's activity on the I-IV cycle after conducting action research through the group guidance service on improving the academic efficacy of students, it is known that counselor activity can be carried out well. The results of observing the counselor activity can be briefly seen in the following table:

Table 1 . The results of observing the counselor activity

\begin{tabular}{|c|c|c|}
\hline Cycle & Councelor's activity & Criteria \\
\hline I & 14 & Good \\
\hline II & 21 & Very Good \\
\hline III & 31 & Excellent \\
\hline IV & 36 & Excellent \\
\hline
\end{tabular}

The success of the counselor's activity is influenced by several factors including the efforts to improve the counselor in implementing the group's guiding measures in accordance with the provisions. The accuracy of selecting a group guidance counseling service also contributes to the group's guidance as intended to prevent the development of problems or difficulties in self-contemplated students [16]. In this action research, the delivery of information provided regarding the education problem namely is the academic self-efficacy of students.

Counselors as facilitators must be able to encourage counselees (i.e group members whose problems are being discussed) interact fully with all other group members and absorb and respond to everything that comes from friends for the sake of solving the problems they faced [17].

In addition, the Counsellor seeks to understand the characteristics of the students faced by students of class VIII, which are in early adolescent phases that characterize emotions, demonstrating a very strong sensitive, and reactive nature to various events or social situations. In other words, the development of junior high school students, in general, has an unstable of emotionality. When associated with a study event, this condition makes the youth have no confidence in learning because there is a transition to the physical, cognitive, and social aspects of making adolescent emotionality easy to change [18]. The feeling of teenagers on a particular object is volatile. Such circumstances if not well understood are potentially in conflict, this condition can lead to low academic selfefficacy. 
As a counselor should be able to know and understand deeply the traits of a person, power in a person, feel the power of the soul that encourages someone to do and diagnose the problems of the students, then develop individual potential positively.

The observation results from the observer to the activity of the counselor which of the ten steps in the core activity of the counselor conveys the material that has relation to academic self-efficacy. With the topic "successes and failures of previous learners", students are quite actively listening. After the submission of the material, counselors encourage students to discuss, share their opinions and experiences, and solve problems or perform tasks. Students declare to participate in group activities by discussing, sharing opinions, and expressing impressions and outcomes. Then the student commits to making promises to maintain confidentiality, assist each other in discussing, and resolve issues at each meeting. From cycle I to cycle IV indicate an increase to the category of excellent for counselor activity, and for students ' activities to be a very active category. This means that at every meeting there is an increase from the activity of counselors, where the counselor was initially still not very clear in delivering the rules in the guidance of the group so that many students who do not understand the guidance steps The group. In addition, when delivering material to each meeting there are still students who are ashamed to ask and choose silence so that when counselors encourage students to discuss, share their opinions and experiences, and solve problems or do Assignments, students only look at each other and choose to wait for their friend to express their opinion (passive students). The results of observing the counselor activity can be briefly seen in the following table:

Table 2. The results of observing the student activity

\begin{tabular}{|c|c|c|}
\hline Cycle & $\begin{array}{c}\text { Students } \\
\text { activities }\end{array}$ & Criteria \\
\hline I & 8 & Quite active \\
\hline II & 10 & Active \\
\hline III & 11 & Active \\
\hline IV & 15 & Very active \\
\hline
\end{tabular}

The results of observations on student activities in the first cycle to the fourth cycle at each meeting showed an increase to the very active category. Achievement of these indicators of success is due to the implementation of group guidance to improve academic self-efficacy of students of class VIII SMPN 25 Banjarmasin because of student enthusiasm in carrying out activities consisting of 4 aspects: (1) can maintain confidentiality, (b) help each other in discussing and solving problems, (c) listen to the material presented and (4) discuss, share opinions and express the impressions and results of the activities.

Group activities are aimed at improving and developing self-understanding and environmental understanding, self-adjustment, and self-development. Providing more interesting information by using varied media also by filling the questionnaire so that students can learn about the potential in learning.

In general, group activities use the principles and processes of group dynamics such as in discussion activities, Sociodrama, role-playing, simulation and others. Guidance through group activity is more effective because in addition to more active individual roles, it also allows the occurrence of thought exchanges, experiences, plans and problem solving [14].

Based on the results of action in the effort to increase students' self-efficacy in learning through group guidance, each cycle has increased. This means that shows have achieved indicators of success in enhancing students' self-efficacy in learning.

With give attention to the characteristics of the students who are given a guidance service this group is the first category of youth (class VIII) who have an interest in recreational and entertainment, interest in socializing are quite high so that the academic affairs does not become the top priority for them. So the roles of teachers and parents, must remind the students that they can accomplish their learning tasks and continue to motivate them in order to maintain even if they need to improve their confidence in learning that they can accomplish academic assignments well.

The role of a counselor in school is also important, through the provision of guidance and counseling services that have been programmed to help subject teachers and parents to improve academic self-efficacy. One of the guidance and counseling services implemented in the school is a group guidance service.

In general, group guidance services aim to develop social skills, especially communication skills of service participants (students). More specifically, group guidance services aim to encourage the development of feelings, thoughts, perceptions, insights and attitudes that support more effective manifestations of behavior, namely the improvement of verbal and nonverbal communication skills of students [19]. Seeing this goal, it is appropriate for group guidance services to encourage the development of insights and attitudes about self-efficacy.

In everyday life, self-efficacy leads us to determine challenging ideals and persist in the face of difficulties [20]. Academic self-efficacy can be formed and developed from four ways or sources of information [8]. The four ways are enactive mastery experience, 
vicarious experience, social persuasion, and physical and emotional states.

Through group guidance services, developing the enactive mastery experience, vicarious experience, social persuasion, and physical and emotional states, can improve student's academic self-efficacy. The four ways are carried out in the guidance of the group with the three phases: (1) The formation stage, (2) The transitional stage, and (3) the activity stage, so that students can recognize the strength of himself so that they have confidence in learning, able to make Verbal reinforcement to be able to accomplish tasks in learning, and be able to rely on feelings in assessing their abilities [11]. Individual interpretation of their physical and mood state, affecting the individual's self-efficacy, so that through activity on group guidance services can give meaning to students to be able to interpret the physical and mood conditions so that they are confident in their ability to learn.

\section{CONCLUSION}

Thus the group guidance service can be said to effectively help students experience a change of behavior in learning that is to have confidence in learning so that it has the confidence to be able to accomplish difficult tasks and Face challenges in learning. This is supported by counselor activities that improve the step of each meeting, and the understanding of students. Student activities also support group guidance to be effective, because students will discuss and follow all activities enthusiastically. Further researchers are expected to implement group guidance services to increase or decrease other variables, such as self-confidence, self-acceptance, self-resilience, selfadaptation.

\section{ACKNOWLEDGMENTS}

We would like to express our gratitude to the leaders of the University of Lambung Mangkurat who have provided the opportunity administratively, and counselors, and students who have provided sources of information related to this research.

\section{REFERENCES}

[1] Wernersbach, B M., Crowley, S L., Bates, S C. \& Rosenthal, C, 2014, Study Skills Course Impact on Academic Self Efficacy. Journal of Developmental Education, 37 (3), pp. 14-33.

[2] Gafoor, A., Ashraf, M, 2012, Influence of SchoolImage on Academic Self Efficacy Belief. Innovations and Research in Education, 2 (1), 5158

[3] Onyeizugbo, E U, 2010, Self-Efficacy and Test
Anxiety as Correlates of Academic Performance. Educational Research, 1 (10), pp. 477-480

[4] Akomolafe, M J., Ogunmakin, O., \& Fasooto, G M, 2013, The Role of Academic Self-Efficacy, Academic Motivation and Academic Self-Concept in Predicting Secondary School Students' Academic Performance. Journal of Education and Social Research, 3 (2), pp. 335-342. DOI: DOI: 10.5901/jesr.2013.v3n2p335

[5] Bandura, A, 1997, Self Efficacy: the exercise of control. New York: Freeman.

[6] Mohhamadi, S., Ghamari, M., Jafari, A. \& Nani, K.Y.M. 2014. The Effect of Group Counseling Based on Reality Therapy on Self-Efficacy of Guidance Girl Students. Journal of Social Issue \& Humanities, 2 (9).

[7] Hermita, M.,\& Thamrin, W. P, 2014, Metacognition Toward Academic Self Efficacy Among Indonesian Private University Scholarship Students. Procedia Social and Behavioral Science, 171 (268), pp. 1075-1080. DOI DOI: 10.1016/j.sbspro.2015.01.268

[8] Pajares, F, 2002, Overview of Social Cognitive Theory and of Self Efficacy. (Online), (http://people.wku.edu/richard.miller/banduratheor y.pdf).

[9] Ummah, A H, 2012, Efektivitas Konseling Ringkas Berpusat Solusi Untuk Meningkatkan Efikasi Diri Akademik Siswa Sekolah Menengah Pertama (SMP). Tesis tidak diterbitkan. Malang: PPs UM.

[10] Zimmerman, B J. 2000. Self Efficacy: An Essential Motive to Learn. Contemporary Educational Psychology, 25 (1), 82-91. DOI: doi:10.1006/ceps.1999.1016.

[11] Bandura, A, 1994, Self Efficacy. San Diego: Academic Press.

[12] Hartinah, S, 2009, Konsep Dasar Bimbingan Kelompok. Bandung: Refika Aditama.

[13] Romlah, T, 2001, Teori dan Praktek Bimbingan Kelompok. Malang: Penerbit Universitas Negeri Malang.

[14] Irawati, R, 2016, Keefektifan Konseling Realita dengan Visual Art Untuk Meningkatkan Efikasi Diri Akademik Siswa SMA. Tesis tidak diterbitkan. Malang: PPs UM.

[15] Kemmis, S., \& McTaggart, R, 1982, The action research planner. Victoria, Australia: Deakin University.

[16] Nurihsan, J, 2017, Strategi Layanan Bimbingan dan Konseling. Bandung: PT Refika Aditama

[17] Sukardi, D K, 2008, Metodologi Penelitian Pendidikan, Kompetensi dan Praktiknya. Jakarta: Bumi Aksara. 
[18] Direktorat Jenderal Guru Dan Tenaga Kependidikan, 2016, Panduan Operasional Penyelenggaraan Bimbingan Dan Konseling Sekolah Menengah Pertama (SMP). Jakarta: Kementerian Pendidikan Dan Kebudayaan.

[19] Tohirin, 2015, Bimbingan dan Konseling di Sekolah dan Madrasah. Jakarta: PT Raja Grafindo.

[20] Ghufran, M N., \& Rinawita, S, 2012, Teori-teori Psikologi. Jogyakarta: Ar-Ruzz Media. 